\title{
Decision-making as a Predictor of Problem-solving Skills in 5-6-year-old Children
}

\begin{tabular}{ccc}
\hline $\begin{array}{c}\text { Article Type } \\
\text { Research }\end{array}$ & $\begin{array}{c}\text { Received Date } \\
21.10 .2019\end{array}$ & $\begin{array}{c}\text { Accepted Date } \\
8.10 .2020\end{array}$ \\
\hline & & \\
Serpil Pekdoğan* & & Esra Akgül $^{* *}$
\end{tabular}

\begin{abstract}
The objective of this study is to analyze decision-making skills as a predictor of problem-solving abilities in children aged 5-6 years. The sample set was comprised of 124 children ages 5-6 years in pre-schools in the mid Black Sea region in Turkey. Personal information forms, the ProblemSolving Ability Scale, and the Decision-Making Skill Assessment Scale-Children's Form were used in the study. In the analysis of data obtained from the study, Pearson's product-moment correlation coefficient was used in order to determine the relationship between variables, and multiple regression analysis was used in order to determine the predictor capacities of independent and dependent variables. According to results of the study, determination, independent decision-making, and feelings in decision-making - the tested categories of decisionmaking skills - are predictors of problem-solving abilities, hesitation in decision-making has not been acknowledged to be a significant factor in predicting problem-solving abilities.
\end{abstract}

Keywords: Child, problem solving, decision making, social development.

\footnotetext{
${ }^{*}$ Assoc. Prof. Dr., Inonu University, Faculty of Education, Department of Early Childhood Education, Malatya, Turkey. E-mail: serpil.pekdogan@inonu.edu.tr, https://orcid.org/0000-0003-0027-3001

${ }^{* *}$ Ress. Assist., Hacettepe University, Faculty of Education, Department of Early Childhood Education, Ankara, Turkey. E-mail:esra.kose@ @acettepe.edu.tr, https://orcid.org/0000-0002-8155-4181
} 


\title{
5-6 Yaş Çocuklarda Problem Çözme Becerisinin Yordayıcısı Olarak Karar Verme
}

\begin{tabular}{ccc}
\hline Makale Türü & Başvuru Tarihi & Kabul Tarihi \\
Araştırma & 21.10 .2019 & 8.10 .2020 \\
\hline
\end{tabular}

$$
\text { Serpil Pekdoğan* }
$$

\author{
Esra Akgül***
}

\begin{abstract}
$\ddot{O} \mathbf{z}$
Çocukların sosyal-bilişsel yönden uyumlu olmalarının ön koşullarından olan problem çözme ve karar verme becerileri, okul öncesi dönemden itibaren oldukça önemlidir. Bu çalışmanın amac1 56 yaş çocuklarda problem çözme becerisinin yordayıcısı olarak karar verme becerilerinin incelenmesidir. Araştırmanın örneklemini 2018 yılı güz döneminde Orta Karadeniz bölgesinde okul öncesi eğitime devam eden, 5-6 yaş aralığındaki 124 çocuk oluşturmaktadır. Araştırmada kişisel bilgi formu, Problem Çözme Becerisi Ölçeği ve Karar Verme Becerileri Değerlendirme Aracı-Çocuk Formu kullanılmıştır. Tarama modelindeki bu çalışmadan elde edilen verilerin analizinde değişkenler arasındaki ilişkiyi belirlemek amacıyla Pearson Momentler Çarpımı Korelasyon Katsayısı, bağımsız değişkenlerin bağımlı değişkeni yordayıcı gücünü belirlemek amacıyla da çoklu regresyon analizi kullanılmıştır. Araştırmanın sonuçlarına göre; karar verme becerilerinin alt boyutlarından olan kararlı olma, bağımsız karar verme ve karar vermede duygular becerilerinin, problem çözme becerilerinin yordayıcısı olduğu görülürken, kararda zorlanma becerisinin problem çözme becerisini anlamlı düzeyde yordamadığı görülmüştür. Araştırmadan elde edilen bulgular çeşitli araştırmalar ve ilgili alanyazın 1şığında tartışılmıştır.
\end{abstract}

Anahtar Sözcükler: Çocuk, problem çözme, karar verme, sosyal gelişim.

\footnotetext{
* Doç. Dr., İnönü Üniversitesi, Eğitim Fakültesi Temel Eğitim Bölümü Malatya, Türkiye. E-posta: serpil.pekdogan@inonu.edu.tr, https://orcid.org/0000-0003-0027-3001

** Arş. Gör., Hacettepe Üniversitesi Eğitim Fakültesi Temel Eğitim Bölümü, Ankara, Türkiye.

E-posta:esra.kose@hacettepe.edu.tr, https://orcid.org/0000-0002-8155-4181
} 


\section{Introduction}

Knowledge alone is not enough for children to be successful in the world. In order for children to continue in the modern world, they must acquire 21 st century skills such as problem solving, creativity, innovation, metacognition, and communication. Problem solving skill is one of the basic human cognitive processes. Problems arise when children are faced with a situation in which they don't know the way to complete a task. Problem solving is a process that involves systematic observation and critical thinking to find a suitable solution or way to achieve the desired goal (Rahman, 2019).This demonstrates the need to rethink how we will educate young people to develop problem-solving competencies that create critical and creative problem solvers for the future society (Wirth \& Klieme, 2003).

Children who develop socially and emotionally during the pre-school period have good interpersonal and problem-solving skills. From babyhood onward, a child's ability to convey emotions, desires, and intentions to others, to know how to act in the face of a problem, to participate in sharing activities, and to cope with conflicts is an important marker in evaluating social and emotional development (Koruklu, 2010). A child's problem-solving abilities constitute a crucial part of social and emotional development in the context of social adaption.

Regarding problem-solving ability development in children, Piaget's theory of cognitive development states that 7-8-month-old babies in the sensorimotor stage develop behavioral patterns for a specific purpose. For example, a baby pulling the blanket under a distant toy in order to get it closer is among the behavioral patterns related to problem-solving ability (Willats, 1990). As development continues, 10-12-month-old babies begin to solve problems through analogy. They develop their problem-solving abilities by using objects in varying ways (Chen, Sanchez \& Campbell, 1997; McCarty \& Keen, 2005). After the first two years, babies develop their problem-solving abilities through trial and error methods and forming mental representations (Berk, 2013).

Babies 12-18 months old use mental images when combining previously learned problemsolving methods, while those aged 18-24 months use these images when solving new problems. The child starts to walk in 18-24-month stage and solves problems by using reflective thoughts and mental images for the first time in his/her life. In this process, the child examines the problem, explores available solutions, and puts them into practice to solve the problem (Trawick-Smith \& Smith, 2014). Children learn from everything they experience. Because they are regularly faced with unfamiliar situations, their problem-solving abilities develop in accordance with their cognitive capacity, which increases as they grow and experience more. For a 3-year old, putting on shoes, or for a 6-year old, understanding how car wheels spin, is a problem-solving opportunity. The child encounters a new situation, and if he/she cannot find a solution through known methods, then he/she faces a problem (Aydoğan, 2012). Numerous studies exist regarding the problem-solving processes of pre-school children (Shure, 1993; Ayles \& Glenn, 1989; Tegano, Lookabaugh, May \& Burdette, 1991; Kasik \& Gal, 2016; Lue, Wishon, McDevitt \& Welsh, 1997; Davenport, Hegland \& Merby, 2008).

In the problem-solving process, children come face to face with decision-making, prediction, and ambiguous situations (Dinçer Atilla, 1995). Problem-solving ability is defined as a mental and actual process involving an effort to overcome difficulties for a specific purpose. This includes evaluating options that could be effective in overcoming the difficulty and selecting the most effective options (Bingham, 1958; D’Zurilla \& Goldfried, 1971). Sub-stages of problem-solving ability include determining a purpose, gathering options, assessing the options, selecting the optimal option, and applying it to the difficulty under consideration (Byrnes, 2002). Taken together, the basic stages of problem-solving involve defining and analyzing the problem, producing options, and decision-making assessment (Heppner, 1988). In this context, the abilities of problem-solving and decision-making are seen to constitute a whole. The phrases "problem-solving" and "decision-making" are sometimes used interchangeably, since they are similar to and, in some cases, dependent on each other (Finkelman, 2001). While making a decision, a child collects information, receives feedback from other people, elaborates on the information, and makes predictions (Tan \& Temiz, 2003). The decision-making process involves many cognitive stages such as studying and collecting information, solving problems, learning new information, and accessing memory (Diniz, 2005). Considering the fact that 
problem-solving abilities develop early in children, it is safe to say that decision-making abilities develop simultaneously.

Children garner various experiences when obtaining information and frequently encounter problems to be solved along the way. They suggest solutions for problems, discuss them, implement plans, cooperate with other people, and reach a conclusion (Aydoğan, 2012). The decision-making process that comes along with those skills is a part of a child's cognitive development. Pre-school children are extremely capable of making decisions by thinking about their own behaviors and are typically eager to evaluate circumstances in their lives (Epstein, 2003). Thinking skills and contemplation processes are necessary components in the development of decision-making and problem-solving abilities (Pekdoğan, 2015). After children start becoming active in defining and identifying their environment, thinking processes begin to develop. Metacognitive processes-e.g. decision-making, planning, observing, and assessing - within the thinking process lead children to contemplation (Fisher, 2005; Sternberg, 2003). When children contemplate, they become aware of what kind of things are attractive to them, how they feel about them, and how they can experience them. Actually, encountering problems starts the contemplation process for children. The child then uses problem-solving strategies with a view to eliminating obstacles, expressing feelings and desires, creating solutions, predicting outcomes, and supporting their own ideas (Evans, 2002).

Children are conscious of getting results in the decision-making process, just like adults are. A child encountering a problem first investigates the difficulty and considers potential solutions via the decision-making process. Next, he/she finds an answer semi-automatically, tries to apply the solution, and then investigates again in order to discover the effectiveness of the potential solution. In the third stage, the child reaches a conclusion about the effectiveness of their processes (Byrnes, 2002). Development of such thinking skills enables children to learn about decision-making, which in turn forms the basis of problem-solving and responsibility skills, as well as the ability to organize their own behaviors and cope with complex situations (Epstein, 2003).

Studies about problem-solving and decision-making abilities in adults or older age groups exist in the related literature (Heppner, Hibel \& Neal, 1982; Aydın, Birol \& Demir, 2017; Phillips, Pazienza \& Ferrin, 1984; Arın, 2006; Güçray, 2001). In addition to those studies, research is currently being done on problem-solving and decision-making abilities in the pre-school period. The quality, the developmental process, and the importance of problem-solving abilities in the pre-school period have led scholars to both experimental and descriptive studies on this topic and others related to it (Anliak \& Dinçer, 2005; Şahin \& Yıldırım, 2006; Tavl1, 2007; Özdil, 2008; Karg1, 2009; Durmuşoğlu Saltalı \& Deniz, 2010; Yaralı \& Özkan, 2016; Webster-Stratton, Reid \& Hammond, 2001; Erwin, Firth \& Purves, 2004; Domitrovich, Cortes \& Greenberg, 2007; Mills et al., 2012). The lack of studies that parallel the development of decision-making and problem-solving abilities in young children, however, deserves notice. This study aims to contribute to the body of literature on child development by considering the connection between decision-making and problem-solving abilities as a precondition for children to be socially and cognitively adaptive from the pre-school period onward.

\section{Method}

This section includes the research model and sample set, data collection tools, data collection, and data analysis.

\section{Research Design}

This research is a relational study within the framework of a descriptive survey model. Its objective is to analyze decision-making skills as a predictor of problem-solving abilities in 5-6-yearold children in enrolled in pre-school in 2018 fall semester. Descriptive survey models seek to describe and examine the current status and characteristics of groups within their own conditions, while relational survey models aim to determine the existence of a relationship between two or more variables (Cohen, Manion \& Morrison, 2000; Heppner, Wampold \& Kivlighan, 2008). 


\section{Research Sample / Study Group}

The research sample set was comprised of 124 children between 5-6 years old continuing their pre-school education. $58 \%$ of the children were female $(n=72)$, while $42 \%$ were male $(n=52) .55 \%$ of the children included in the sample were 5 years old $(n=68)$, while $45 \%$ were 6 years old $(n=56)$. The children participating in the study were selected through simple random sampling (Büyüköztürk et al., 2017).

\section{Research Instruments and Procedures}

Personal information forms, the Problem-Solving Ability Scale (PSAS) developed by Oğuz and Köksal Akyol (2015), and the Decision-Making Skill Assessment Scale_Children's Form (DMSASCF) developed by Pekdoğan (2015) were used to collect data for the study.

Personal Information Forms: This form, created by the researcher, included demographical information such as the child's age, gender, and pre-school education history.

The Problem-Solving Ability Scale (PSAS): Created by Oğuz and Köksal Akyol (2015), the Problem-Solving Ability Scale (PSAS) is a 5-point Likert scale. Measuring the problem-solving abilities of children ages 60-72 months, this assessment tool includes 18 illustrated problems. The assessment provides statements and illustrations describing every problem. Solutions offered for a given problem are scored from 0 to 4 . When a child is presented with a problem, they receive points for proposing solutions. If the child does not offer any solutions, 0 points are given. If he/she suggests 1 solution, 1 point is given. If 2 suggestions, 2 points are given. If 3,3 points are given. If 4 or more suggestions are offered, 4 points are given. In order for a child to receive points from the solutions he/she creates, each solution must be different from the others. In the application phase, the child may repeat a solution suggestion he/she has previously offered. In this case, no points are given to the repeated solution suggestions. The scoring spectrum in PSAS is 0-72. A high PSAS score indicates a high problem-solving ability. In order to determine the reliability of an assessment tool with one category, its Cronbach's Alpha reliability coefficient was calculated and found to be $\alpha=.86$ (Oğuz \& Köksal Akyol, 2015).

The Decision-Making Skill Assessment Scale-Children's Form (DMSAS-CF): This tool was created by Pekdoğan (2015) to assess decision-making skills of 5-6-year-old children, including factors such as hesitation in decision-making (HDM), independent decision-making (IDM), determination (D), and feelings in decision-making (FDM). The assessment is applied to children. Composed of 29 questions in 4 categories, the form is scored via "yes" (1) and "no" (0) answers. In this assessment, there are 5 decision-making situations that children encounter on a daily basis, and 5 statements related to those situations. In the category of hesitation in decision-making (HDM), questions measuring hesitation capacities are included. Each affirmative answer to these questions increases hesitation levels in children while each non-affirmative answer increases their determination levels. In the independent decision-making (IDM) category, the questions evaluate the dependent decision-making abilities of children. Each non-affirmative answer means an increase in independence levels while affirmative answers indicate an increase in dependency levels. The determination (D) category includes questions related to indecision. Non-affirmative answers denote a quality of determination; affirmative answers measure indecision levels. In the category of feelings in decisionmaking (FDM), feelings of regret, distress, and sadness caused by decisions are examined. Affirmative answers indicate emotional decision-making behavior, and non-affirmative answers indicate no emotional effects on decision-making. Thus, as children score lower on the form, their decision-making skills are indicated to be higher. In order to determine the reliability of the assessment, its Cronbach's Alpha reliability coefficient was calculated. In "Decision-Making Skill Assessment Scale-Children's Form," the reliability coefficients of the categores "Determination (D)," "Hesitation in Decision-Making (HDM)," "Independent Decision-Making (IDM)," and "Feelings in Decision-Making (FDM)" were calculated to be $\alpha=.83, \alpha=.81, \alpha=.78$, and $\alpha=.79$, respectively, while the reliability coefficient of the "Decision-Making Skill Assessment ScaleChildren's Form" itself was found out to be $\alpha=.89$ (Pekdoğan, 2015). 


\section{Data Collection}

After receiving necessary permissions from the provincial directorate of Ministry of Family and Social Policies in the province where data collection would be performed, 136 children, aged 5-6, enrolled in private kindergartens were included in the study. The study was conducted on a volunteer basis, and 12 children who did not want to participate or did not complete the questions on the forms were left out of the scope of the study. Consequently, the 124 children who fully met the study criteria were included in the research. Before beginning the data collection, the researcher and the child entered a secure and comfortable location where the researcher informed the children of the process before beginning the evaluation. The evaluations were then applied to the child one at a time. Each test lasted approximately 25 minutes. The personal information of the child was removed from the study files afterward.

\section{Data Analysis}

Data analysis was conducted using the SPSS 18.0 software package. For the assumptions of normality, the Kolmogorov-Smirnov test, the coefficients of skewness and the kurtosis values were simultaneously examined. Büyüköztürk (2013) stated that, when testing whether the values drawn from continuous variables are distributed normally, if the coefficient of skewness and the kurtosis values are found to be between \pm 1 , the values can be said to be distributed normally. Based on the results of the data analysis, it was concluded that the coefficient of skewness and the kurtosis values were calculated to be between \pm 1 and that data was distributed normally ( $p>05)$. Due to the normal distribution of data, Pearson's correlation analysis was used to determine the relationship between the decision-making skills and the problem-solving abilities of 5-6-year-old children.

Multiple regression analysis was used to examine the decision-making skills of 5-6-year-old children as a predictor of their problem-solving abilities. Multiple regression analysis enables the relationship between variables to be analyzed in a multidimensional way in survey research. In this study, the standardized (direct) method, one of multiple regression analysis methods, was used. In the standardized (direct) method, all the variables having an effect on the dependent variable are included in the equation (Büyüköztürk, 2013). For multiple regression analysis, extreme variables included in the analysis to determine whether data was distributed normally were examined. In order to determine the extreme variables, Mahalanobis' distance values were calculated. A significance level of .001 for Mahalanobis' distance was desired. Data points above this value were removed from the dataset, and the study was continued with 124 data points. Standardized deviation values and the expected cumulative probability distribution graph was analyzed through the data obtained, which was acknowledged to correspond to the assumptions of normality following the analysis of obtained data and graphs (Büyüköztürk, 2013).

\section{Results}

In this section of the study, multiple regression results regarding, first, the relationship between the decision-making skills and the problem-solving abilities of children, and, second, their decisionmaking skills as a predictor of their problem-solving abilities are presented in Table 1.

\section{Table 1}

Correlation coefficients and descriptive statistics among variables

\begin{tabular}{llllllll}
\hline Variables & 1 & 2 & 3 & 4 & 5 & $\overline{\mathrm{X}}$ & $S D$ \\
\hline Determination & 1 & & & & 9.21 & 2.05 \\
Hesitation & $.488^{* *}$ & 1 & & & 2.23 & .94 \\
B & $347^{* *}$ & 116 & 1 & & 2.58 & .97 \\
Independence & $369^{* *}$ & .127 & $.384^{* *}$ & 1 & & 2.50 & 1.03 \\
Feelings & $.329^{* *}$ & $-.496^{* *}$ & $-.459^{* *}$ & 1 & 34.32 & 7.66 \\
Problem Solving & $-.549^{* *}$ & $-.229^{*}$ & & & & & \\
\hline
\end{tabular}

**p $<.01$ 
Based on the results in Table 1, it can be said that there was a moderate relationship between a child's problem-solving abilities and determination skills $(\mathrm{r}=-.549, \mathrm{p}<.01)$. While a lower level of relationship between problem-solving skills and hesitation in decision-making levels was observed $(\mathrm{r}$ $=-.229, \mathrm{p}<.01$ ), a moderate relationship between problem-solving abilities and independent decisionmaking skills was found $(r=-.496, p<.01)$. It was also observed that there was a moderate relationship between problem-solving abilities and feelings in decision-making $(r=-.459, \mathrm{p}<.01)$. Therefore, it can be said that as the indecision, hesitation, dependent decision-making and feelings-affected decisionmaking levels of children decrease, their problem-solving abilities increase. The results of the multiple regression analysis, performed in order to determine to what extent the categories of decision-making skills in 5-6-year-old children predict their problem-solving abilities, are presented in Table 2.

Table 2

Multiple regression analysis results regarding the prediction of problem-solving skills

\begin{tabular}{llcccc}
\hline \multicolumn{1}{c}{ Predictor Variable } & $\mathbf{B}$ & Standard Error & $\boldsymbol{\beta}$ & $\mathbf{t}$ & $\mathbf{p}$ \\
\hline Stable & 56.226 & 2.516 & & 22.360 & .000 \\
Determination & -1.265 & .311 & -.346 & -4.068 & .000 \\
Hesitation & .093 & .649 & .011 & .143 & .887 \\
Independence & -2.347 & .605 & -.298 & -3.878 & .000 \\
Feelings & -1.826 & .567 & -.246 & -3.221 & .002 \\
$\mathrm{R}=.66, \mathrm{R}^{2}=.43$ & & & & & \\
$\mathrm{~F}=22.561, \mathrm{p}=.00$ & & & & & \\
\hline
\end{tabular}

When the multiple regression analysis results were examined, the model was seen to be significant as a whole $(\mathrm{R}=.66, \mathrm{R} 2=.43, \mathrm{~F}=22.561, \mathrm{p}=.00)$. Predictor variables explained $43 \%$ of the total variance in problem-solving abilities. According to the standardized regression coefficient $(\beta)$, the order of significance of the predictor variables is as follows: determination $(\beta=-.346, p<.01)$, independent decision making $(\beta=-.298, \mathrm{p}<.01)$, and feelings in decision-making $(\beta=-.246, \mathrm{p}<.01)$. The hesitation in decision-making variable in the model does not contribute to the regression model even though it is related to the variables $(\beta=-.143, p>.05)$. In light of these results, it can be said that determination makes the greatest contribution to the prediction of children's problem-solving abilities. The skills of independent decision-making and feelings in decision-making are also significant factors in predicting problem-solving skills. The hesitation in decision-making variable did not contribute to the model, however, since it was found statistically insignificant ( $p>05)$.

\section{Discussion, Conclusion and Recommendations}

According to the results of the study, the variables predicting 5-6-year-old children's problemsolving skills were determination, independent decision-making, and feelings in decision-making. These variables account for $43 \%$ of problem-solving abilities. It was concluded that the hesitation in decision-making variable did not contribute to the prediction of problem-solving abilities. It was also demonstrated that problem-solving ability is related to the component categories of decision-making.

When children encounter problems in their daily lives, their decision-making skills come into play. As a child encounters more problems, he/she uses his/her decision-making on higher levels. Decision-making skills are a social process and an integral part of gaining life experience (Grose, 2007; Lundberg \& Romich, 2006; Barkley, Cross \& Major, 2005; Levin \& Hart, 2003; Madge \& Willmott, 2004; Landsdown, 2001; Paxton \& John, 1997; Dunne \& Bennett, 1994). In the study, the categories of determination, independent decision-making, and feelings in decision-making were seen to be important predictors of problem-solving abilities. The complexity of children's logic, their attachment to ideas and feelings in line with their own desires, and their sub-conscious thought processes seem to play an instrumental part as well (Piaget, 1934; Wood, 2003). Because no prediction quality regarding children's hesitation in decision-making was encountered in the study, this seems to indicate that children are more concentrated on the results than on the process. In the pre-school period, children's problem-solving abilities are limited to the preoperational stage (Oğuz \& Köksal Akyol, 2015). Since children exhibit egocentric behaviors, they automatically seek solutions to the problems they encounter and use their decision-making processes in parallel with their mental 
development. In her study, Davidson (1991) asserts that the decision-making skills of children become more differentiated as their age increases, and they tend to make sharper decisions and concentrate on processes more as they grow older. In another study, empty boxes and boxes containing decisionmaking scenarios with different risk factors were presented to pre-school children. The children were asked to select empty boxes or decision boxes. The study demonstrated that children become aware of risk factors in decision-making after they are 4 years old. Prior to that, they think primarily about results when making decisions; they do not concentrate on the process but rather seek direct solutions to problematic situations (Levin \& Hart, 2003).

Problem-solving skills form the basis of learning. Children learn how to think thoroughly about a subject, establish a cause-and-effect relationship, assess options, and make decisions through their problem-solving habits (Aydoğan \& Ömeroğlu, 2004; Garon \& Moore, 2004). In order for a child to cope with a problematic situation, he/she needs to envision alternatives and choose the most effective solution option (Batıgün Durak, 2000). The correlation between problem-solving abilities and determination skills revealed in this study supports this idea. In their longitudinal study, Levin et al. (2007) presented risky problematic situations for children and asked them to make decisions accordingly. The conclusion of that study revealed that the children made problem-solving decisions by concentrating on the results rather than the process. Garon \& Moore (2004) stated that as children advance through the pre-school phase (3-6 years old), their understanding capacities increase. They create more potential solutions and think more linearly when making decisions. Therefore, their decision-making skills get better. The fact that pre-school children rely so heavily on determination, independent decision-making, and feelings in decision-making indicates that they are concentrated on the results.

The results obtained from this study highlight a lack of research addressing the relationship between children's problem-solving abilities and their decision-making skills. The limitations of the sample set of this study - children enrolled in private kindergartens in a province in the mid Black Sea region-hinders a comprehensive assessment and generalization. In addition to that, the age limitations (i.e., 5-6-year-olds) also narrow the impact of the results. In light of this, it is evident that longitudinal studies elaborating on children's problem-solving abilities and decision-making skills ought to be carried out within the related literature. Experimental studies could be performed by organizing programs that support children's decision-making skills and include their problem-solving processes. When children are given opportunities to exercise their problem-solving abilities, their cognitive skills such as deciding, observing, comparing, organizing, and assessing information develop, and they also gain relational skills and habits (Goffin \& Tull, 1985). Considering the importance of problem-solving abilities and decision-making skills in the lives of children, educational endeavors supporting these skills could be added to curricula. Similar studies performed on different research samples would provide wider insight and value.

\section{References}

Anlıak, Ş., \& Dinçer, Ç. (2005). Developing Interpersonal Cognitive Problem Solving Skills in Preschool Period. Eurasian Journal of Educational Research, 20,122-134.

Aydogan, Y. (2012). Problem Solving and Supporting Problem Skills (Ed: Ömeroğlu, E.), 2nd edition. Ankara: Kök Publishing. [Aydoğan, Y. (2012). Problem Çözme Ve Problem Becerilerinin Desteklenmesi (Editör: Ömeroğlu, E), 2. baskı. Ankara: Kök Yayıncılık.]

Batıün Durak, A. (2000). Problem solving therapies: definition and evaluation. Turkish Journal of Psychology, 6(19), 40-49.

Bingham, A. (1958). Developing problem solving skills in children. İstanbul: National Education Press.

Büyüköztürk, Ş. (2004). Data analysis manual for social sciences. Ankara: Pegem A Publishing. [Büyüköztürk, Ş. (2013). Sosyal bilimler için veri analizi el kitabı istatistik, araştırma deseni SPSS uygulamalart ve yorum. Ankara: PegemA Yayıncılık.] 
Buyukozturk, S., Cakmak, E. K., Akgun, Ö. E., Black Sea, S., \& Demirel, F. (2017). Scientific research methods. Ankara: PegemA Publishing. [Büyüköztürk, Ş., Çakmak, E. K., Akgün, Ö. E., Karadeniz, Ş., \& Demirel, F. (2017). Bilimsel araştırma yöntemleri. Ankara: PegemA Yayıncilik.]

Byrnes, J. P. (2002). The development of decision-making. Journal of Adolescent Health, 31, 208215.

Chen, Z., Sanchez, R. P., \& Campbell, T. (1997). From beyond to within their grasp: the rudiments of analogical problem solving in 10-and 13-month-olds. Developmental psychology, 33(5), 790.

Cohen, L. M., \& Morrison, L. K.(2000).Research methods in education. London and New York: Falmer.

Davidson, D. (1991).Children's decision-making examined with an information-board procedure. Cognitive-Development, 6, 77-90.

Dinçer-Atilla, F. Ç. (1995). The Examination of the effect of "problem solving" training on the arquisition of interpersonal problem solving skills by five year old children attending a kinder garten. [Unpublished doctoral dissertation]. Hacettepe University, Ankara.

Diniz, Ş. H. (2005). The Effect of Decision Making Skills Education Program on the Decision Making Skills of Primary School Senior Students. Serdar Erkan and Alim Kaya (Ed.), In Experimentally Tested Group Counseling and Guidance Programs (pp. 387-437). Ankara: PegemA.

D'zurilla, T.J \& Goldfried, M.R. (1971). Problems solving and behavior modification. Journal Of Abnormal Psiychology, 18, 407-426.

Domitrovich, C. E., Cortes, R. C., \& Greenberg, M. T. (2007). Improving young children's social and emotional competence: A randomized trial of the preschool "PATHS" curriculum. The Journal of primary prevention, 28(2), 67-91.

Durmuşoğlu Saltalı, N. \& Deniz, M.E. (2010). The effects of an emotional education program on the emotional skills of six-year-old children attending preschool, Educational Sciences: Theory \& Practice, 10(4), 2105-2140

Epstein, A. S. (2003). How Planning and Reflection Develop Young Children's Thinking Skills. Young Children, 58(5), 28-36.

Erwin, P. G., Firth, K., \& Purves, D. G. (2004). Task characteristics and performance in interpersonal cognitive problem solving. The Journal of Psychology, 138(2), 185-192.

Evans, B. (2002). You can't come to my birthday party! Conflict resolution with young children. Ypsilanti, MI:High/Scope.

Finkelman, A. W. (2001). Problem-solving, decision-making, and critical thinking: how do they mix and why bother? Home care provider, 6(6), 194-198

Fisher, R. (2005). Teaching Thinking (2nd edition). London: Continuum Books.

Garon, N., \& Moore, C. (2004). Complex decision-making in early childhood. Brain Cognition, 55, $158-70$.

Goffin, S. G., \& Tull, C. Q. (1985). Problem solving: Encouraging active learning. Young Children, $40(3), 28-32$.

Heppner, P. P. (1988). A review of the problem-solving literature and its relationship to the counseling process. Journal of Counseling Psychology, 25, 366-375.

Heppner, P. P., Wampold, B. E., \& Kivlighan, D. M. (2008). Quantitative descriptive designs. Research designs in counseling, 3, 224-255. 
Karg1, E. (2009).The effectiveness of the interpersonal cognitive problem-solving program: An investigation children who attend preschool. [Unpublished doctoral dissertation]. Ankara University, Ankara.

Koruklu, N. (2010). The effect of conflict resolution and mediation education on problem solving behavior of 6 years old children. Adnan Menderes University Faculty of Education Journal of Educational Sciences, 1(1), 1-20.

Levin, I. P., \& Hart, S. S. (2003). Risk preferences in young children: Early evidence of individual differences in reaction to potential gains and losses. Journal of Behavioral Decision Making, 16(5), 397-413.

Levin I, Weller J, Pederson A, \& Harshman L. (2007). Age-related differences in adaptive decision making: Sensitivity to expected value in risky choice. Judgment and Decision Making, 2, 225233.

McCarty, M. E., \& Keen, R. (2005). Facilitating problem-solving performance among 9-and 12month-old infants. Journal of Cognition and Development, 6(2), 209-228.

Mills, C. M., Danovitch, J. H., Grant, M. G., \& Elashi, F. B. (2012). Little pitchers use their big ears: Preschoolers solve problems by listening to others ask questions. Child development, 83(2), 568580.

Oğuz, V., \& Akyol, A. K. (2015). Problem-Solving Skills Scale (PSSS) Validity and Reliability. Cukurova University Faculty of Education Journal, 44(1).

Özdil, G. (2008). The effect of interpersonal problem solving program on interpersonal problem solving ability education program's among the children who keep going their preschool education. [UnpublishedMasterThesis]. Adnan Menderes University, Aydın.

Pekdoğan, S. (2015). Examination of the effect of the Decision Making Skills Education Programme 5-6 year old children's decision making skills. [UnpublishedDoctoral Thesis]. Gazi University, Ankara.

Piaget, J. (1934). Cognitive development in children. İstanbul: Cem Psikoloji.

Rahman, M. M. (2019). 21st century skill "problem solving": defining the concept. Asian Journal of Interdisciplinary Research, 2(1), 64-74.

Shure, M. B. (1997). Interpersonal cognitive problem solving: Primary prevention of early high-risk behaviors in the preschool and primary years. In G. W. Albee \& T. P. Gullotta (Eds.), Issues in children's and families' lives, Vol. 6. Primary prevention works (pp. 167-188). Thousand Oaks, CA, US: Sage Publications, Inc.

Sternberg, R. J. (2003). Wisdom, intelligence, and creativity synthesized. Cambridge University Press.

Şahin, F., \& Yıldırım, M. (2006). A research about case-based problem solving at preschool. [Okul öncesinde örnek olaya dayalı problem çözme ile ilgili bir araştırma.] I. International Preschool Education Conference, June 30-July 3 2004, Congress Book (Vol. 1).

Tan, M. ve Temiz, B.K. (2003). The importance and role of the science process skills in science teachıng. Pamukkale University Journal of Education, 1 (13), 89-101.

Tavl1, B.(2007). The survey of 6-age preschool students problem solving skills as compratively.[UnpublishedMasterThesis]. Abant İzzet Baysal University, Bolu.

Trawick-Smith, J. W., \& Smith, T. (2014). Early childhood development: A multicultural perspective. Upper Saddle River, NJ: Pearson.

Yaralı K.T. \& Özkan H.K. (2016). Examınatıon of relatıon between children's (60- 72 months) social problem-solving skills with social competence and behavioral status. The Journal of Turkish Social Research 2, 345-361. 
Webster-Stratton, C., Reid, M. J., \& Hammond, M. (2001). Preventing conduct problems, promoting social competence: A parent and teacher training partnership in Head Start. Journal of clinical child psychology, 30(3), 283-302.

Willatts, P. (1990). Development of problem-solving strategies in infancy. Children's strategies: Contemporary views of cognitive development, 23-66.

Wirth, J., \& Klieme, E. (2003). Computer-based assessment of problem solving competence. Assessment in Education: Principles, Policy \& Practice, 10(3), 329-345.

Wood, D. (2003).Thinking and learning in children. (M. Özünlü, Translate.). İstanbul: Doruk. 
